\title{
育苗時と定植後におけるミナミキイロアザミウマの 発生程度の関係について
}

\author{
藤岡 理* ・福田 涉* ・ 北野裕士* - 谷川典宏* \\ 野山智司*・根来淳一*・晒 一浩* \\ Satoru FUJIOKA*, Wataru FUKUDA*, \\ Hiroshi KitanO*, Norihiro TANIGAWA*, \\ Satoshi NOYAMA*, Jun-ichi NEGORO* \\ and Kazuhiro SARASHI* : \\ Relationships between Occurrence of \\ Thrips palmi KARNY, \\ and Before and After Planting of Seedlings
}

\section{Summary}

Densities of Thrips palmi KARNY on eggplant leaves were investigated before and after planting of seedlings in 273 plastic houses in the Minamikawachi district of Osaka Prefecture. There was positive correlation between the densities before and after planting which means that effective control before planting suppresses the occurrence of this species after planting. The investigation also showed that mulching ridges with polyvinyl film improved the effects of insecticide spraying.

\begin{abstract}
緒
言

大阪府南河内地区農業改良普及所管内ではナス栽培 が非常に盛んであり，1984 年にミナミキイロアザミウ マの発生が確認されて以来, その防除技術の確立が最 重要課題となった。この課題を解決するため, 府, 市 町村, 農協が一体となって各種の試験ほや実証展示ほ を設けた2_5)。その過程で, 八ウス栽培ナスにおいては 育苗時期の徹底防除が定植後の発生密度抑制に最も効 果的であることが明らかになった。

筆者らは，1990 年 12 月〜 1991 年 3 月に管内の半促 成ナス栽培農家全戸 (273 戸) を対象に, 育苗期及び本 ぽ定植後におけるミナミキイロアザミウマの発生程 度，ならびに定植後の㑼面ポリビニールフィルムマル チの有無について調査を行った結果, 育苗時期の徹底 防除の重要性及び定植後のポリフィルムマルチの防除 効果について具体的な知見を得たのでその結果を報告 する。
\end{abstract}

本文に先立ち, 本稿の取りまとめに当たってご助言, ご校閲をいただいた大阪府農林技術センタ一環境部木 村裕部長, 害虫研究室田中寛研究員, ならびにこれま で試験ほ・展示ほを設置, 運営してこられた南河内地 区農業改良普及所の諸先輩方に深謝の意を表する。

\section{調查方法}

\section{1. 調査ほ場}

調査は管内のハウス栽培ナス産地である富田林市, 河南町，太子町，千早赤阪村の栽培農家全戸 (273 戸) について行った。この地域の作型は 12〜2月に定植し, 7 月上旬まで収穫を続ける半促成栽培がほとんどを占 め, 抑制栽培キュウリと組み合わせる栽培体系が多い。 品種については大部分が穂木は千両二号, 台木はヒラ ナス（赤なす）となっている。この他に一部で穂木に 千両，台木に耐病 VF が使用されている。

\section{2. 䏍苗時調査}

生息密度調査は鉢上げ（接木活着後の苗を直径

*大阪府南河内地区農業改良普及所：Minamikawachi Agricultural Extension Office, Tondabayashi,Osaka 584, 1992 年 2 月 7 日受理 Japan. 
15〜 $18 \mathrm{~cm}$ のポットに植え替えること) 時から定植 1 週 間前までの間に行った（1990 年 12 月中旬〜1991 年 1 月中旬)。調査方法は各戸の育苗八ウス 1 棟について 2〜4 人がそれぞれ任意に 3 か所から 3 株を選び, 上位 3 葉 (計 54 ～108 葉) に寄生するミナミキイロアザミウ マの成幼虫数を計数した。

\section{3. 定植後調査}

生息密度調査は定植の 1 か月〜 1 か月半後に行った (1991 年 2 月上旬 3 月中旬)。調査方法は各農家の八 ウス 1 棟について 2〜 4 人がそれぞれ任意に 5 株を選 び，上位 4 葉（計 $40 〜 80$ 葉）に寄生するミナミキイロ アザミウマの成幼虫数を計数した。

また, 胲面のポりビニールフィルムマルチの有無に ついても調査した。管内では透明, 緑, 黒のマルチ資 材が使用されているが, マルチ資材の色, 種類に関係 なく，マルチの有無のみを調査対象とした。

\section{結果}

育苗時と定植後の結果を第 1 表にとまめて示した。 河合 ${ }^{1}$ はナスにおいて $5 \%$ の果実に被害が発生する成 虫密度は 0.08 個体 /葉であると述べており, 筆者らは これまでの調査で成幼虫密度が 0.5 個体／葉程度から 傷果が多くなることを確認している。そこで, 便宜上 各ハウスで得られた結果を成幼虫密度（1葉当り個体 数)に基づいて $0,0 \sim 0.5,0.5$ 以上の 3 段階の発生程 度に分け，さらにイメージカラーとしてそれぞれに

「青」,「黄」,「赤」を与えた。以後, このイメージカ ラーを用いて話を進める。なお，育苗せずに苗を購入 している農家については育苗時の調査ができなかった ため,「購入苗」として集計を行った。

\section{1. 育苗時の発生程度と定植後の発生程度との関係}

第 1 図に定植後の発生程度を育苗時の発生程度別に 示した。育苗時の発生程度が「青」のうち定植後の発 生程度も「青」(これを「青 $\rightarrow$ 青」と略し, 以降これに 従う）は 53.3\%（107 戸中 57 戸) であったのに対し， 育苗時に発生が見られた「黄」・「赤」については，定

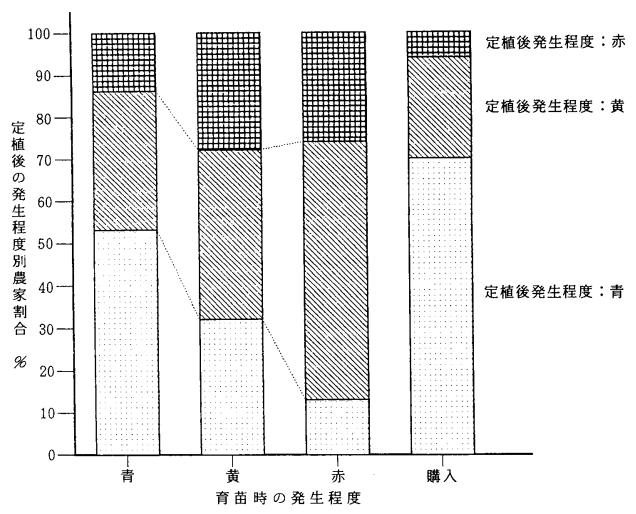

第 1 図 ミナミキイロアザミウマの育苗時の発生程度 と定植後の発生程度の関係

植後に「黄 $\rightarrow$ 青」・「赤 $\rightarrow$ 青」という発生程度の改善が 見られたのは,それぞれ $31.7 \%$ (60戸中 19 戸), $13.3 \%$ (30 戸中 4 戸) であった。なお, 育苗時に発生程度が 「黄」「赤」であった農家に対しては，その時点で警告 を行ったことにより，「青」に比べて防除頻度はかなり 高かったと考えられる。このため, 警告がない場合に はこの差はさらに広がったものと推察される。

一方, 購入苗を使用している農家では, 定植後の発 生程度が「青」のものが $69.7 \%$ （76 戸中 53 戸）であ り, 自家育苗を行っている農家に比べて本種の発生は 少ない傾向が認められた。これは購入苗を育苗した苗 作農家での防除が比較的よく行われていたことを示唆 している。

\section{2. 定植後のマルチの有無と発生程度の関係}

第 2 図にミナミキイロアザミウマの育苗時および定 植後の発生程度と畧面へのポリビニールフィルムマル チの実施状況との関係を示した。まず，はじめに気づ くことは,「赤 $\rightarrow$ 青」はマルチの実施率が $75.0 \%$ (4 戸 中 3 戸) であり，「赤 $\rightarrow$ 黄」の $38.9 \%$ (18 戸中 7 戸)， 「赤 $\rightarrow$ 赤」の $37.5 \%$ (8 戸中 3 戸) に比べて実施率が 顕著に高かったことである。

第 1 表 ミナミキイロアザミウマの発生程度（成幼虫数／葉) 別農家戸数

\begin{tabular}{|c|c|c|c|c|c|}
\hline \multicolumn{2}{|c|}{ 育苗時】定植後： } & $0<$ 青 $>$ & $0 \sim 0.5<$ 黄 $>$ & $0.5 \sim<$ 赤 $>$ & 計 \\
\hline 0 & $<$ 青 $>$ & 57 (19) & $36(22)$ & $14(5)$ & $107(46)$ \\
\hline $0 \sim 0.5$ & <黄 > & $19(12)$ & $24 \quad(17)$ & $17(7)$ & $60(36)$ \\
\hline $0.5 \sim$ & $<$ 赤 $>$ & $4(3)$ & $18(7)$ & $8(3)$ & $30(13)$ \\
\hline 購入苗 & & $53(12)$ & $19(8)$ & $4(3)$ & $76(23)$ \\
\hline 計 & & $133(46)$ & $97(54)$ & 43 (18) & 273 (118) \\
\hline
\end{tabular}

$<>$ : 寄生密度に対応するイメージカラー (本文参照)

（）：畧面ポリビニールフィルムマルチを行っている農家戸数（内数） 


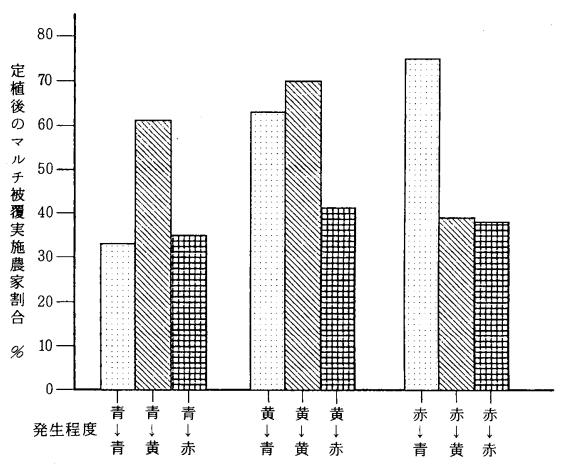

第2図ミナミキイロアザミウマの定植前後の発生程 度と畧面のポリビニルフィルムマルチの関係

同様に，「黄 $\rightarrow$ 青」は $63.2 \%$ (19 戸中 12 戸), 「黄 $\rightarrow$ 黄」は $70.8 \%$ (24戸中 17 戸) であり，「黄 $\rightarrow$ 赤」の 41.1\%（17戸中 7 戸）に比べ実施率は高かった。

一方，「青 $\rightarrow$ 青」・「青 $\rightarrow$ 黄」・「青 $\rightarrow$ 赤」はそれぞれ $33.3 \%$ (57 戸中 19 戸), 61.1\%(36 戸中 22 戸), 35.7\%

(14 戸中 5 戸) であり，マルチの実施率と定植後の発

第 2 表 マルチ実施農家率の高い集落と低い集落にお ける定植後のミナミキイロアザミウマ発生程 度 (成幼虫数/葉) 別農家率 (\%)

\begin{tabular}{cccc}
\hline \hline マルチ実施農家率 & $0<$ 青 $>0$ & $0.5<$ 黄 $>0.5 \sim<$ 赤 $>$ \\
\hline $50 \%$ 以上 & 46.2 & 38.6 & 15.2 \\
$50 \%$ 未満 & 29.3 & 41.5 & 29.2 \\
\hline
\end{tabular}

生程度の関係は小さかった。

第 2 表に定植後のマルチ実施農家率が $50 \%$ 以上の 集落と, $50 \%$ 末満の集落に分けて定植後の発生程度を 比較した。なお，マルチ実施農家率が $50 \%$ 以上の集落 に属するのは 157 戸で，50\%未満の集落 (116戸)に比 ベ 41 戸多い。これを見ると, マルチ実施農家割合が $50 \%$ 以上の集落は $50 \%$ 未満の集落に比べ, 全体的に発 生程度「青」が多く(46.2\%対 $29.3 \%)$,「黄」(38.6\% 対 $41.5 \%$ ）や「赤」（15.2\%対 $29.2 \% ）$ は少なくなっ ている。

\section{考察}

従来から，ミナミキイロアザミウマの防除の原則と して, 育苗ハウス周辺の寄主植物の除去, 育苗時の徹 底防除, 定植後の粒剂の土墒混和処理, 定植後の畧面 ポリビニールフィルムマルチによる蛹化防止等が有効 とされてきた。しかし，これまではいずれも八ウス単
位の小規模な実証実験段階にとどまっており，産地全 体を対象としたこの種のアプローチ（大規模な追跡調 査）は本報告が初めてであると思われる。

今回の調査では，育苗時の発生を抑えることが定植 後の発生に大きく影響しており，育苗時に本種が発生 していなければ，定植後のマルチの有無に関わらず， 定植後の発生程度も全体的に低く抑えられることがわ かった。これは,この地域の作型がほぼ同一で, しか も定植が 12 月下旬〜 2 月上旬であることから，ミナミ キイロアザミウマの主な発生源が苗であるためと考え られる。したがって, 育苗時の発生を抑えれば, 定植 後, 換気にともなって外部からの成虫の飛び込みがあ る 4 月頃までの 3〜4 か月間は, 本種の発生を抑えるこ とが可能になる。

一方，育苗時からミナミキイロアザミウマが発生し ている場合は, 定植直前の徹底防除と定植後の畧面マ ルチによって発生をかなり抑えられることも明らかに なった。とりわけ，育苗時に本種の密度が高いほどマ ルチの効果は高い傾向がみられる。これは, すでに苗 に寄生しているミナミキイロアザミウマを防除する場 合，耕種的な防除は農薬による防除をよく補完するた めであると思われる。

なお，今回は粒剂施用の状況についてはとくに調査 を行わなかったが，管内ではほとんどの農家が定植直 前, または定植時に粒剤を施用していることから, 得 られた結果は，いずれも粒剤施用条件下でのものであ ると見てよい。また，このことは同時に，粒剤施用の みによっては本種の発生を根絶できないことも示して いる。

最近, 田中ら ${ }^{6}$ はナス定植前にハウス内で雑草が繁 茂している場合, 雑草上のミナミキイロアザミウマが 定植後のナスに移動して寄生する可能性を指摘し, 定 植前にハウスを閉め切って内部の温度を上げ，土中の 蛹の羽化を促進するとともに，八ウス内の除草を徹底 して羽化成虫を餓死させることによる防除を提唱して いる。今回の調査および解析手法はこの可能性の検証 ならびに防除法の評価を行う際にも利用できると思わ れる。

\section{摘 要}

大阪府南河内地区農業改良普及所管内の 273 戸の半 促成ナス栽培農家において, 育苗時と定植後にミナミ キイロアザミウマの発生調査を行った。その結果, 本 種は育苗時の発生程度と定植後の発生程度の間に正の 相関があり，育苗時の発生を抑制することにより定植 後の発生も抑制できることが明らかになった。一方, 
育苗時にすでに発生している場合，定植後の畧面ポリ ビニールフィルムマルチは, 定植後の発生程度を低下 させるために必要不可欠であることも示された。なお, 今回用いた手法は今後さまざまな仮説の検証や防除手 段の評価に利用しうると考えられる。

\section{引用文献}

1）河合 章（1986）応動昆 30(3)：179-187.
2 ）木村 裕（1988）農耕および園芸 63(2):325-330.

3 ）木村 裕・田中 寛（1987）関西病虫研報 29:55.

4 ) 北野裕士 (1988) 大阪農業 $26(1): 41-45$.

5 ）那須義次 - 木村 裕 - 辻 博美（1986）関西病虫 研報 $28: 25-29$.

6 ）田中 寛 - 鈴木敏征 - 松下美郎 (1992) 近畿中国 農研 83 (印刷中). 